\title{
An enigmatic and possibly parasitic organism in the tissues of embryonated eggs of Baltic cod Gadus morhua
}

\author{
Buchardt Bloch ${ }^{1}$, Benedikte Hedegaard Pedersen ${ }^{2, *}$, Poul Vagn Jensen ${ }^{3}$ \\ ${ }^{1}$ The Royal Veterinary and Agricultural University, Dept of Veterinary Microbiology, Bülowsvej 13, DK-1870, \\ Frederiksberg C, Denmark \\ ${ }^{2}$ Marine Biological Laboratory, University of Copenhagen, Strandpromenaden 5, DK-3000 Helsingør, Denmark \\ ${ }^{3}$ Laboratory of Cell Biology and Anatomy, Institute of Zoology, University of Copenhagen, Universitetsparken 15 , \\ DK-2100 Copenhagen $\oslash$, Denmark
}

\begin{abstract}
Tissues and interstitial compartments of cod Gadus morhua embryos which were infected by an endoparasite in the yolk were investigated by transmission electron microscopy. Small enigmatic organisms, presumed to be of parasitic nature, were observed in the embryonic cells and tissues. The organisms lacked a cell wall. In addition to intermediate stages, at least 3 distinct stages of the organism were observed. The organisms were located both extra- and intracellularly, in the latter case often surrounded by vacuoles. The stages of the organism differed in their chromatin configurations. One stage contained groups of finely and coarsely flocculated chromatin without a nucleolemma. Juxtapositioned chromatin groups were separated by annulate lamellae. Another stage had one or more nucleus-like elements, each surrounded by a dilated cisterna with a few pores. The cisternae of such adjoining elements formed annulate lamellae, which could break to form a common vacuole. Vacuoles might then fuse with the outer membrane of the organism thereby freeing the nucleus-like elements as daughter elements. Such daughter elements were observed extra- and intracellularly in embryonic cod. The third stage contained several nucleated daughter cells, and lacked annulate lamellae. The identity of the organism is unknown.
\end{abstract}

KEY WORDS: Gadus morhua - Embryos Presumed tissue endoparasites Annulate lamellae

\section{INTRODUCTION}

An endoparasite, believed to be of protistan origin, has been reported in the yolk of embryos and yolksac larvae of cod Gadus morhua and turbot Scophthalmus maximus (Pedersen 1993, Pedersen et al. 1993, Pedersen \& Køie 1994). Transmission electron microscopy (TEM) showed that the spherical parasites in the yolk were multinucleated, and light microscopy indicated that they budded off smaller stages which invaded the larval tissues. The aim of the present study was to identify and describe such tissue stages of the parasite.

•Addressee for correspondence. E-mail: mblkm@inet.uni-c.dk

\section{MATERIALS AND METHODS}

Eggs from wild Baltic cod Gadus morhua were artificially fertilized and incubated in seawater at ca $7^{\circ} \mathrm{C}$. The embryonated eggs were examined with a binocular magnifier $(12-50 \times)$ at $\mathrm{ca} 7^{\circ} \mathrm{C}$ for the presence of parasitic spheres in the yolk (see 'Introduction'). Infected embryos were immersed in TEM fixative (2.5\% glutaraldehyde in $0.1 \mathrm{M}$ cacodylate buffer, $\mathrm{pH} 7.4$ ) and the chorion and yolk-membrane were then perforated with a needle after which the eggs were stored in the cold fixative overnight. After further perforation of the chorion and yolk membrane, the eggs were postfixed in $1 \%$ osmium tetroxide, dehydrated in acetone or ethanol and embedded in Vestopal-W (Serva) or Epon. As controls, embryos without spheres 
in the yolk were fixed using the same protocol and embedded in Vestopal. The controls were taken from a female which had a very low prevalence, $<1 \%$, of embryos containing parasitic spheres in the yolk.

Infected embryos for methyl green-pyronin staining were fixed in $2.5 \%$ formaldehyde with $2.5 \%$ glutaraldehyde and $0.5 \%$ sucrose in cacodylate buffer $(\mathrm{pH} 7.7)$. After dehydration in ethanol they were infiltrated overnight with LR White (type hard) at $4^{\circ} \mathrm{C}$ with agitation. The infiltration continued with fresh LR White at room temperature and with agitation for $1 \mathrm{~h}$, and embedding took place in moulds without air contact. LR White was thermally cured at $45^{\circ} \mathrm{C}$ for $48 \mathrm{~h}$. Serial sections $(1.5 \mu \mathrm{m})$ cut with glass knives were stained with methyl green-pyronin for 30 min (Perry \& Reynolds 1956).

\section{RESULTS}

Semi-thin sections stained with toluidine blue showed pleomorphic organisms, measuring 0.5 to $20 \mu \mathrm{m}$, in the interstice between the yolk membrane and the surrounding embryonic tissues. The organisms were frequently present in the wider part of this interstice close to the trunk of normally developed embryos (Figs. 1 \& 2).

Many organisms were free-floating in the interstice (Fig. 2) or in other cavities in rarely encountered abnormally developed embryos (Fig, 1), while others adhered to similar organisms or to embryonic cells. The organisms were also lodged intercelluarly in the embryo (Fig. 3) and even in the cytoplasm of embryonic cells (Fig. 4). A rim of small vacuoles was often present around intracellular organisms and in a few cases an electron-lucent area of neighbouring fish cytoplasm was observed (Fig. 5). Dead, decaying organisms were frequently present intracellularly, especially in the yolk membrane.

Typical extracellular organisms, measuring 7 to $12 \mu \mathrm{m}$ in largest diameter and found in the above interstice, were spherical or ovoid and sometimes possessed semispherical vacuoles along the otherwise smooth surface. However, as the organisms were surrounded by a plasma membrane only, they were pleomorphic and were able to adapt their shape according to the space available.

Variations in size and shape apart, the organisms varied in electron density due to differences in the number of ribosomes present, but in general the organisms were far darker than the embryonic tissues. As the larger organisms were often divided into 3 zones, their appearance depended on which zones were included in the section. Chromatin and free ribosomes constituted one zone and the often densely packed mitochondria were gathered in another, while the vacuoles were present in the third zone (Fig. 6). The latter zone highly contributed to the pleomor-

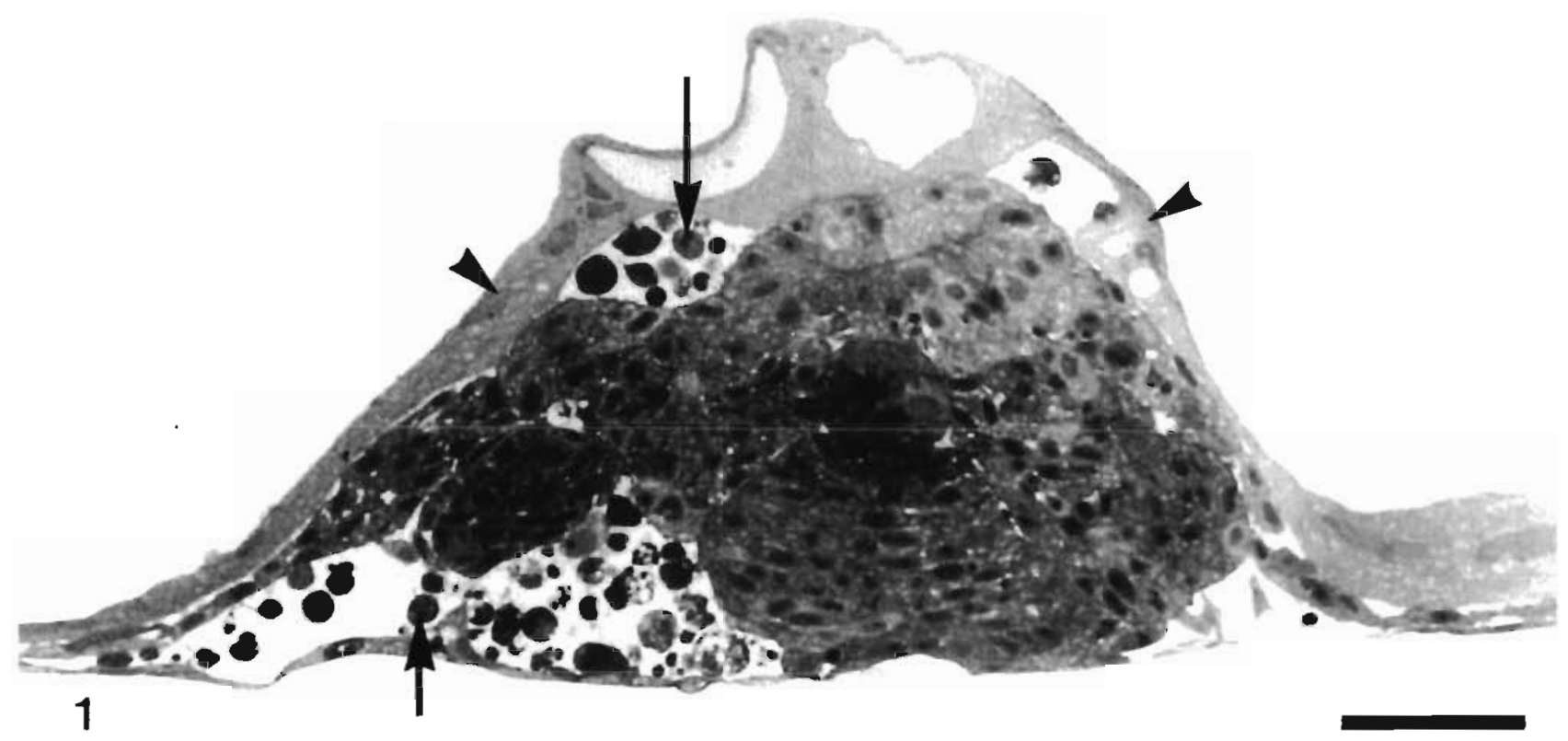

Fig. 1. Gadus morhua. Light micrograph of transverse section of a deformed embryonic body showing spherical and ovoid organisms (arrows), in this case in interstices between the yolk membrane (arrowheads) and the embryonic body, and also in intraembryonic cavities. Although deformed, this embryo was selected as it contains a very high amount of organisms. Usually only a few are seen in a section. Scale bar $=100 \mu \mathrm{m}$ 


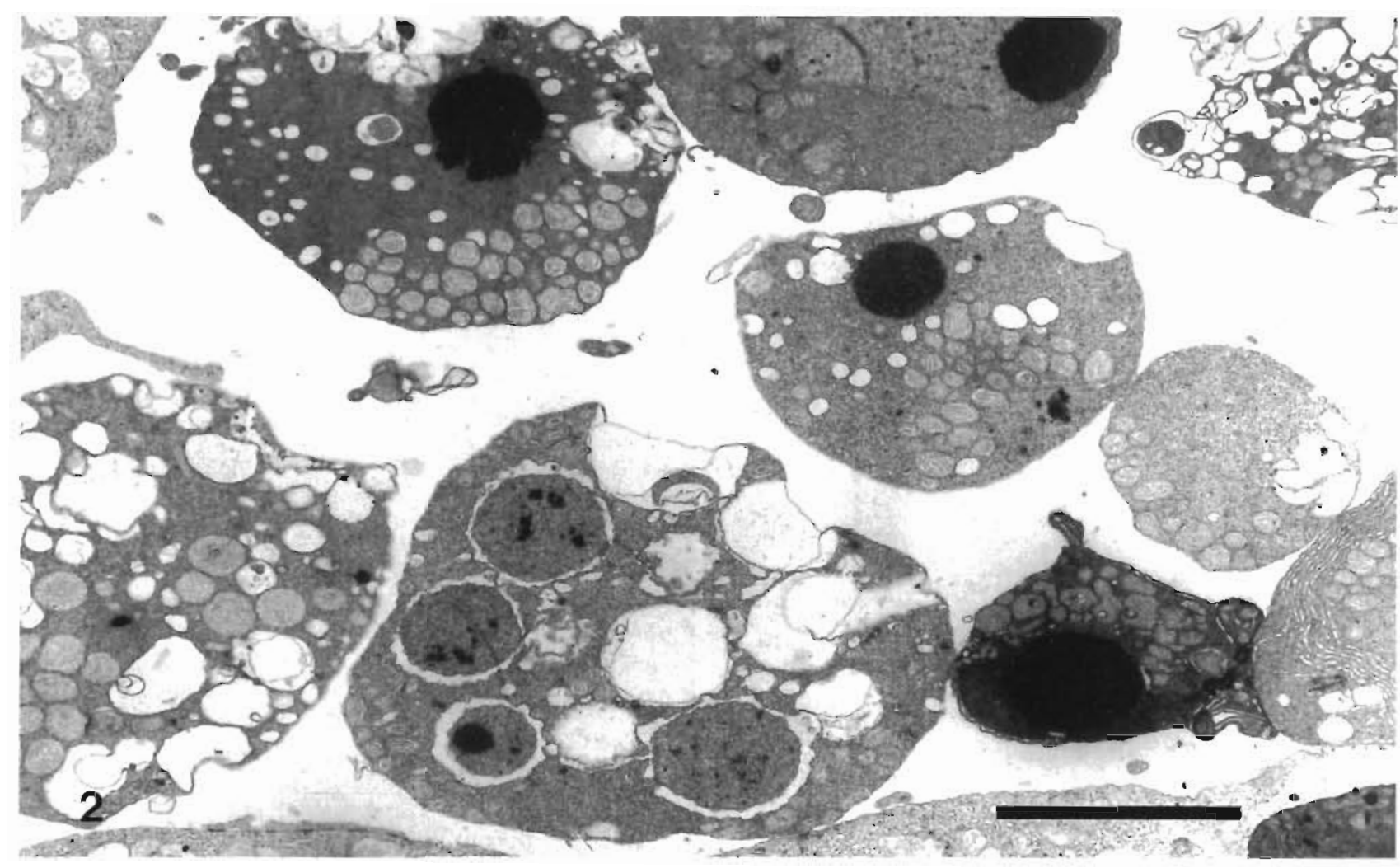

Fig. 2. Gadus morhua. TEM micrograph of parts of 10 organisms located in the interstice between the yolk membrane and the superficial cells of the embryo, shown at the bottom of the picture Note pronounced differences in electron density and in the displayed contents of the organısms Scale bar $=5 \mu \mathrm{m}$

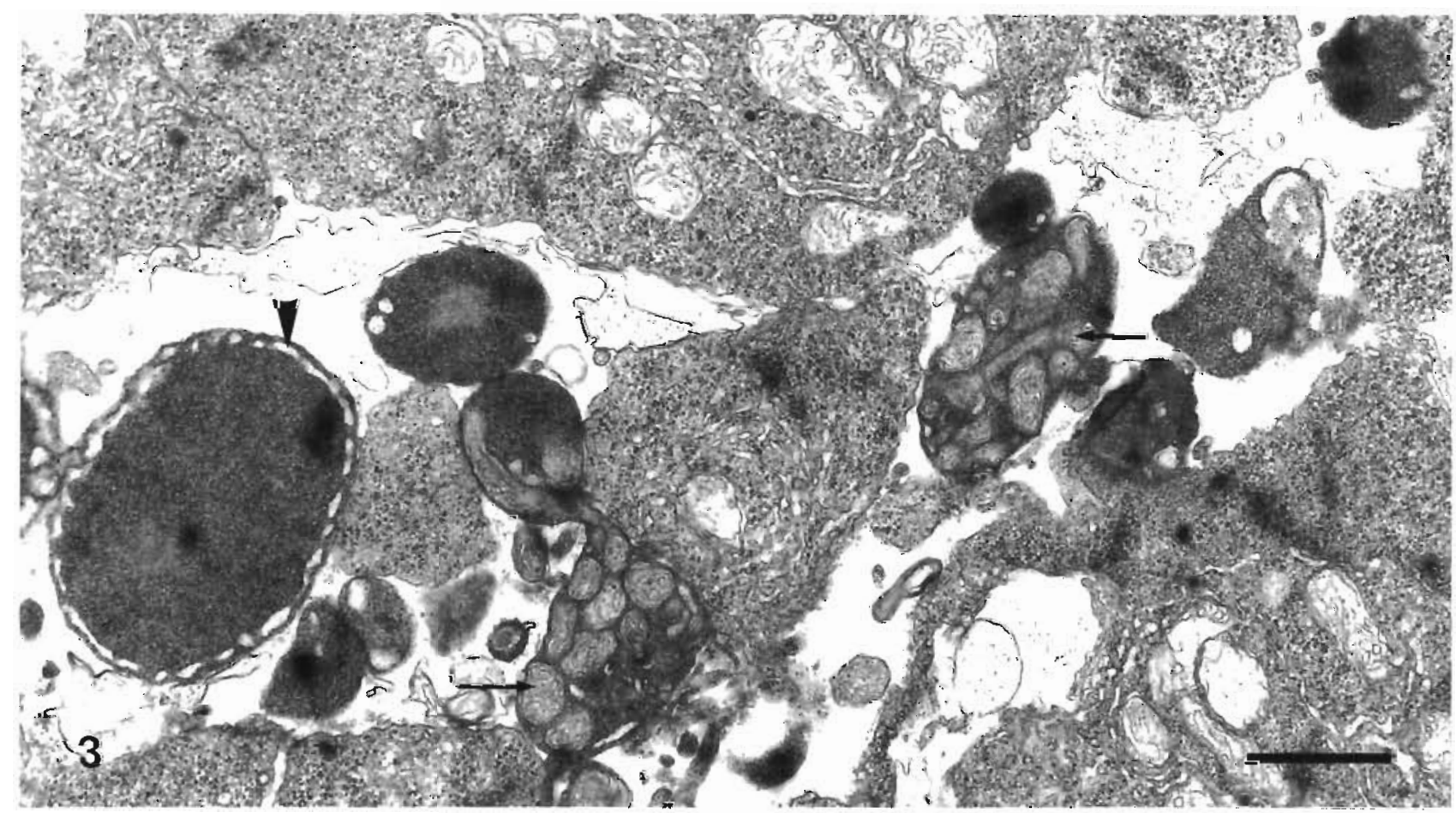

Fig. 3. Intercellular stages of the organism, TEM Note the penpheral cisterna in one of the specimens (arrowhead) sectioned through its main body. Also note the large number of mitochondna in sections of other specimen parts (arrows) These are probably processes belonging to larger organisms. Scale bar $=1 \mu \mathrm{m}$ 


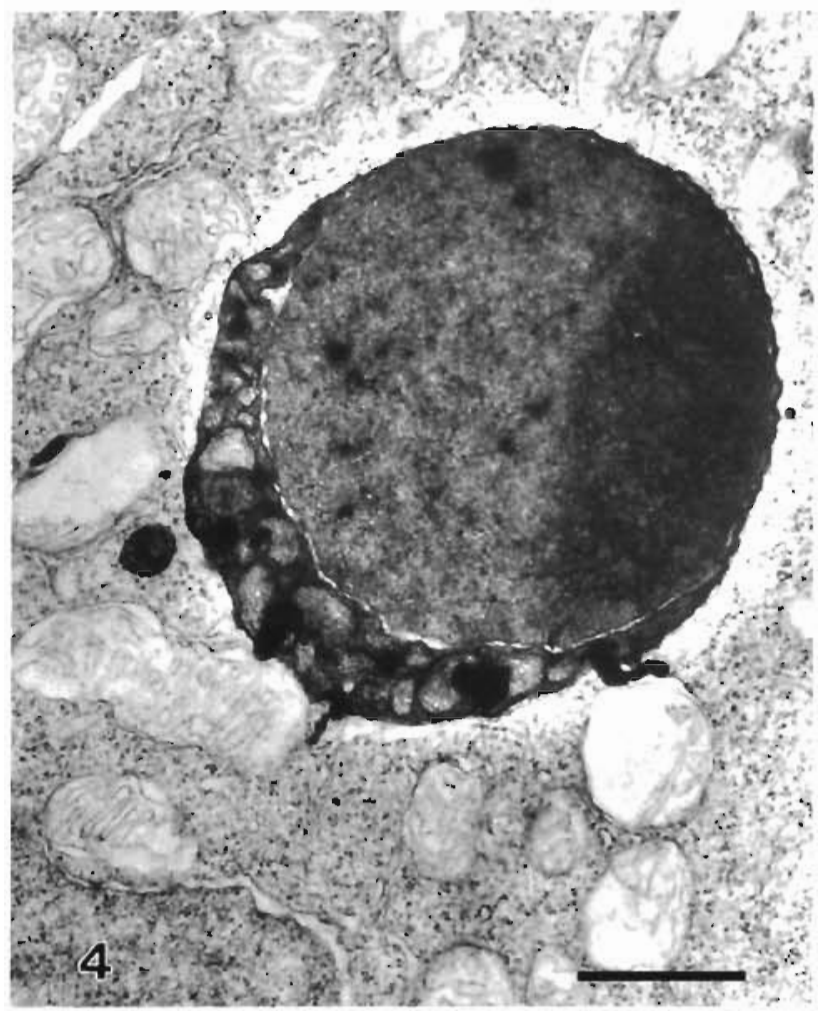

Fig 4 intracellular organism. TEM. The organism is more electron-dense than the fish cell and contains a nucleuslike/daughter element with finely flocculated chromatin and scattered dots of more osmophilic material. The rim of cytoplasm contains mitochondria with myelin figures, some of which are apparently being ejected. Scale bar $=1 \mu \mathrm{m}$

phism due to its looser structure and because the peripheral membranes of the superficial vacuoles could either curve inwards or protude like a bag. Slender processes could also originate from this zone.

On the basis of their chromatin configurations at least 3 groups of organisms could be distinguished. The first group had a dense chromatin sphere without a nucleolemma (Fig. 7). The chromatin often exhibited a composite double configuration, one part forming a dark gray, finely flocculated sphere and the other part consisting of a group of coarsely flocculated black material (see below). In many cells 2 or up to more than 10 such groups of chromatin were placed closely together in the rubosome-containing zone and they were separated from each other by 2 closely positioned flat cisternae of annulate lamellae (Fig. 8).

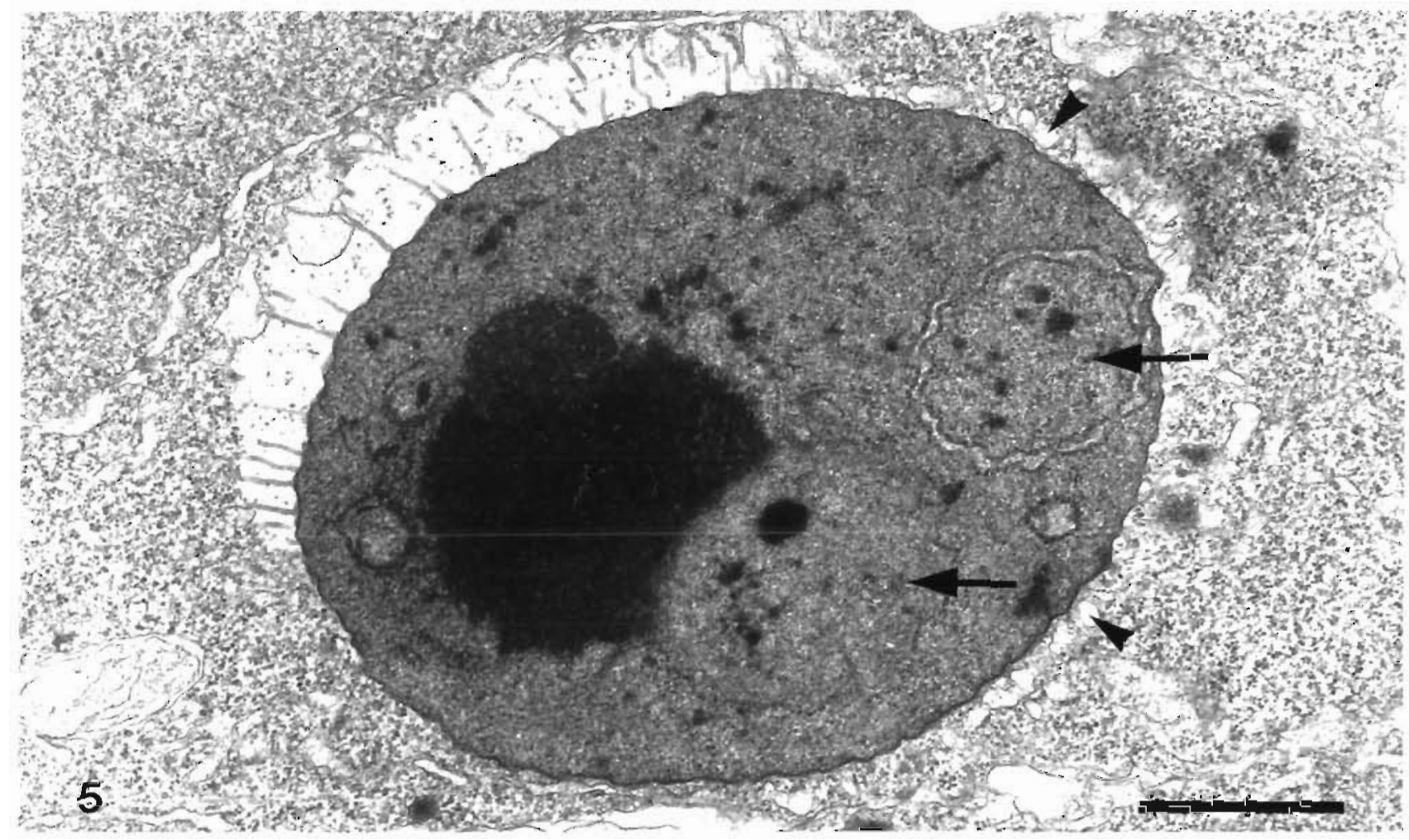

Fig 5 Intracellular organısm, TEM. The organusm contans a partly membrane-enclosed nucleus-like element (lower arrow) in addition to chromatin condensations in the cytoplasm. Small vesicles are located outside part of the periphery of the organism (arrowheads) Along the rest of the penphery of the organısm, a zone vold of nbosomes and organelles is seen. Delicate extensions transverse this zone Note the segmentally sectioned cisterna (upper arrow). Scale bar $=1 \mu \mathrm{m}$ 


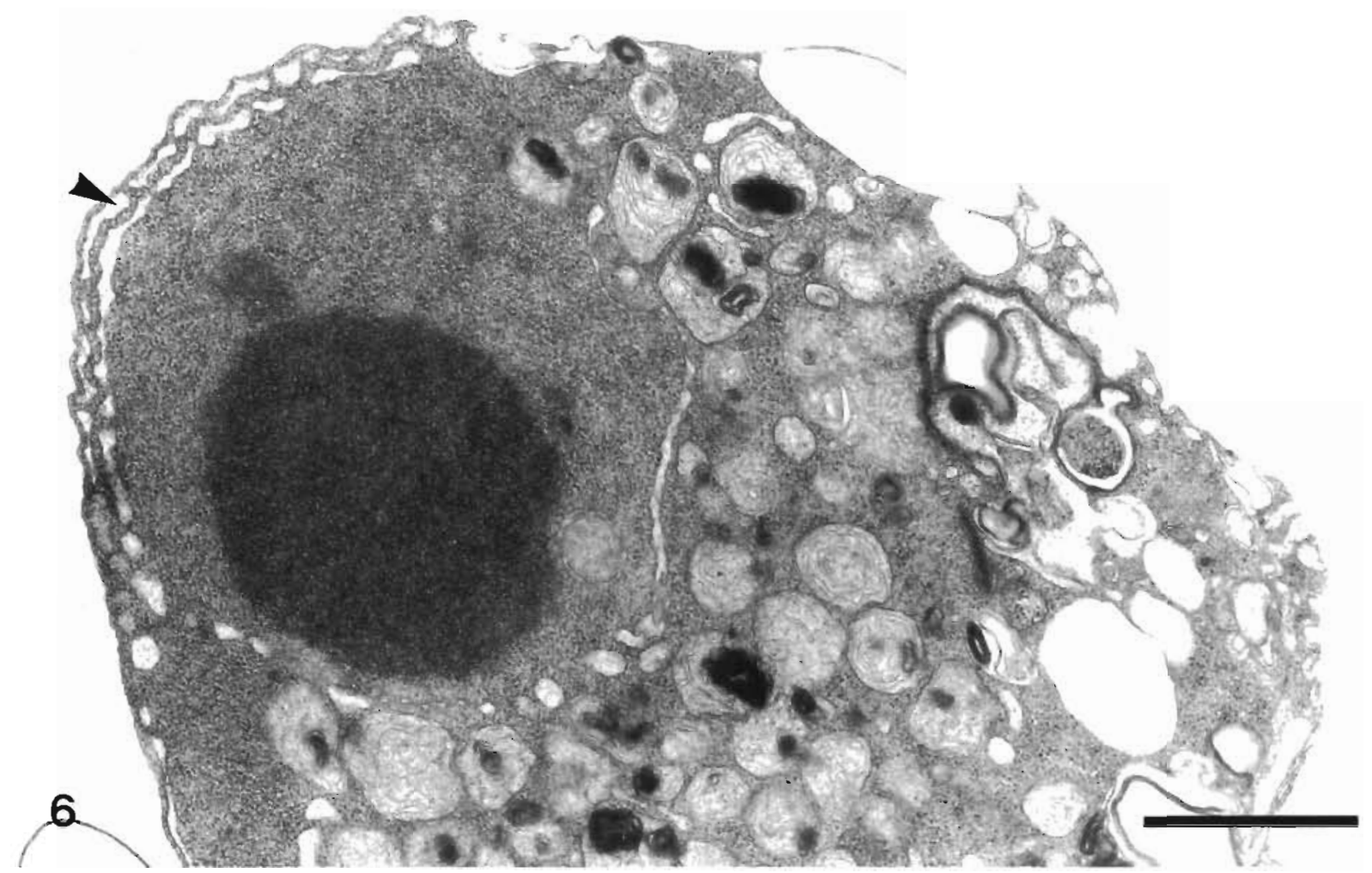

Fig. 6. Part of an extracellular organism, TEM The organism exhibits 3 zones, one containıng nuclear material and ribosomes, another mitochondria - in this case filled with myelın figures - and the third zone containing vacuoles Note the layers of flat vacuoles (arrowhead) along the periphery of the ribosome-containing part of the organism. Scale bar $=1 \mu \mathrm{m}$

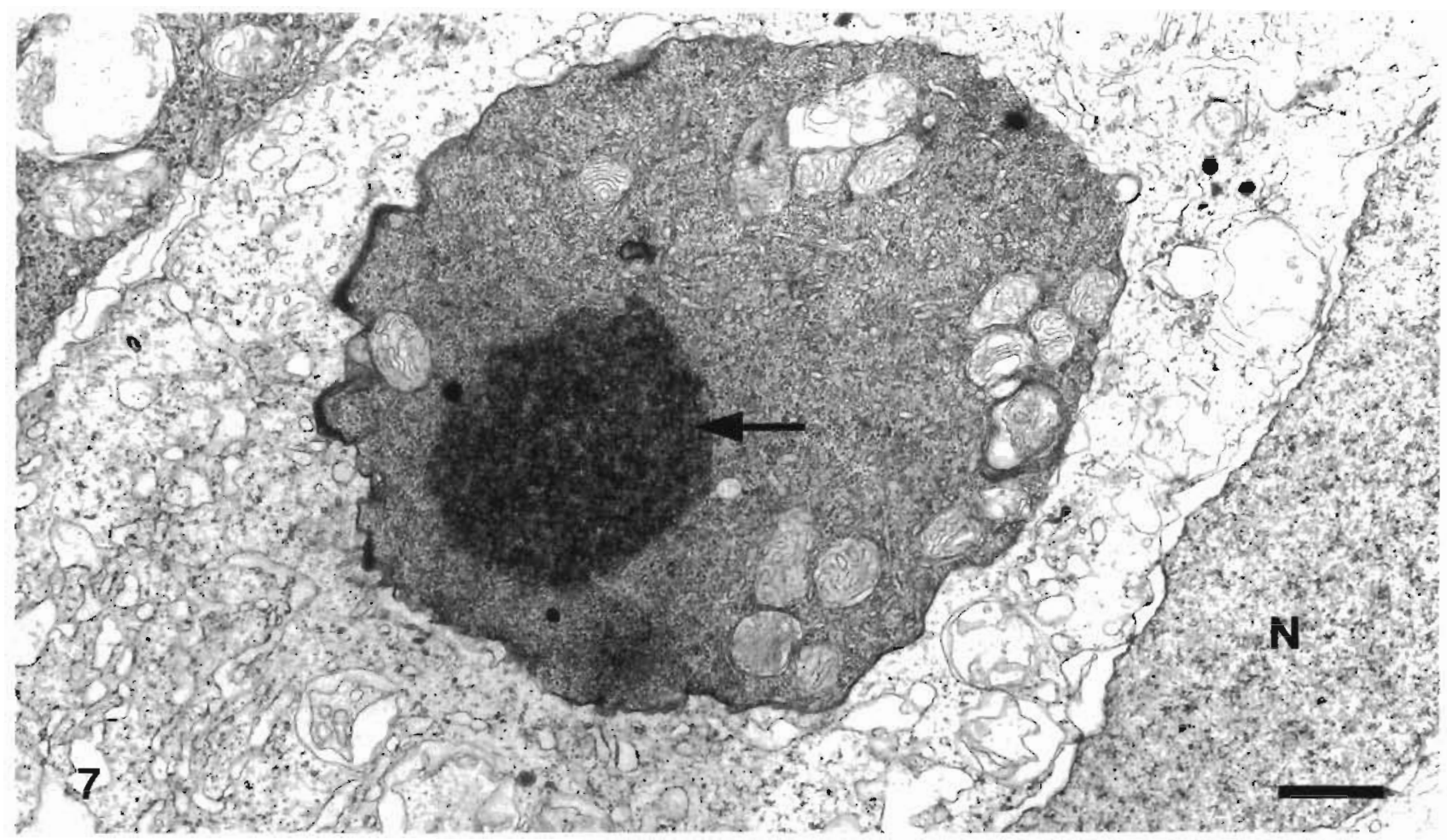

Fig. 7. Intracellular organism, TEM. Specımen belonging to the first group of organisms based on the chromatın configuratıon. The finely flocculated sphere (arrow) is taken to represent nuclear matenal which is not separated from the cytoplasm by a cisterna. $N$. nucleus of the host cell Scale bar $=1 \mu \mathrm{m}$ 


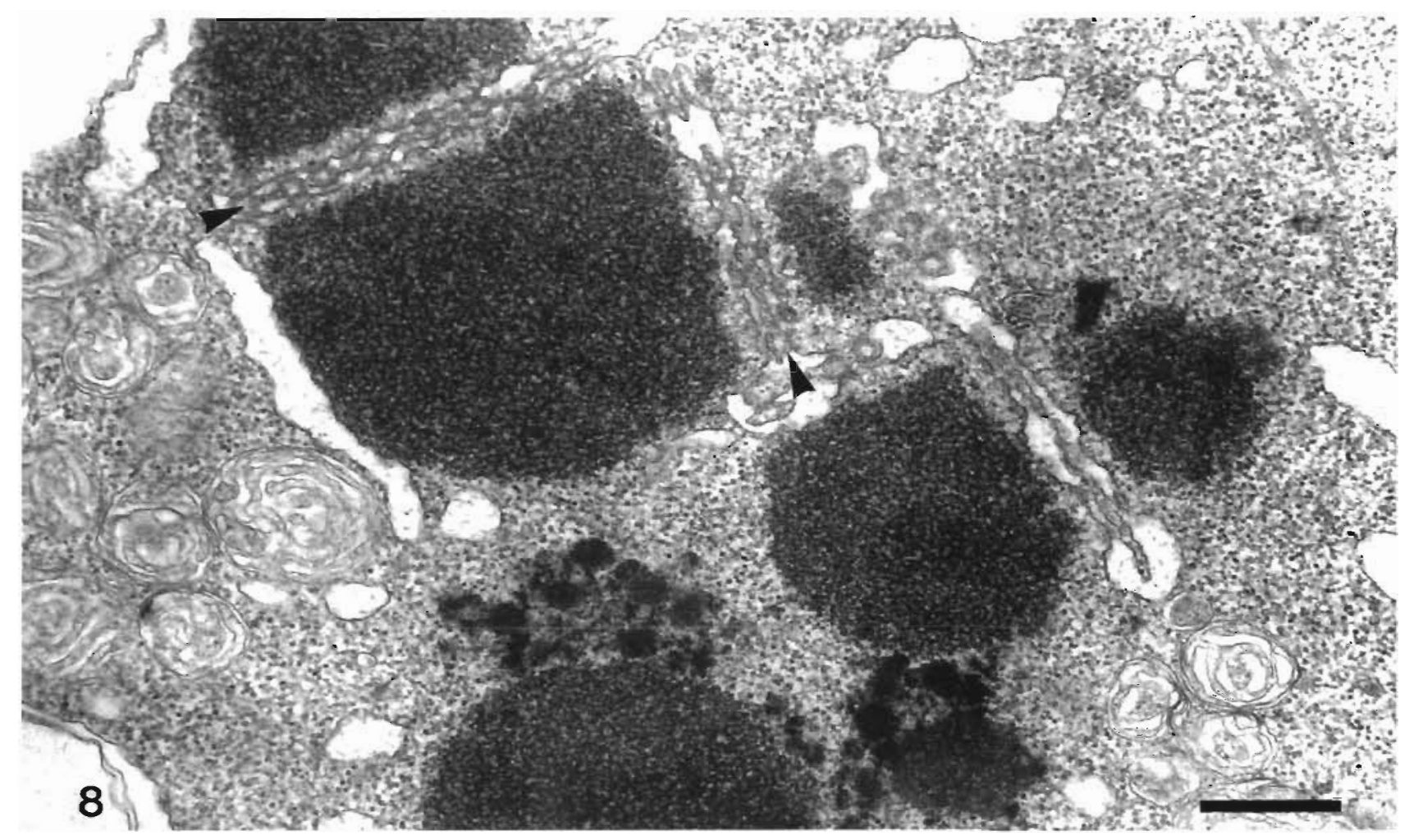

Fig. 8. Part of an extracellular organism, TEM. The closely positioned groups of chromatin are separated by annulate lamellae with 2 cisternae (arrowheads). Note the configuration of the coarsely and finely flocculated chromatin. Scale bar $=0.5 \mu m$

The second group of organisms contained one or more spheric nucleus-like elements/daughter elements, often of nearly the same electron density as the surrounding cytoplasm from which they were separated by a dilated cisterna which in some cases was bridged by a few pores. Such elements were often separated from the exterior of the organism by one or more thin layers of cytoplasm and from adjacent elements by annulate lamellae (Figs. 9, 10, 11 \& 12). Each element contained a dense, finely granulated chromatin sphere, as seen in Group 1 (Fig 7), while the group of darker more coarsely granulated material, also observed in Group 1, could in this situation be scattered as small, black lumps in the plasm of the elements (Figs. 11 \& 13). In some cases the annulate lamellae separating the elements had lost contact not only with the elements but also with the surrounding cytoplasm, rendering the elements free in a vacuole (Fig. 13). An organism could contain only one big element in which one or a few mitochondria or a cisterna might be present, and they appeared in all respects identical to some of the smaller organisms observed both extracellularly and in the embryonic cells (Fig. 7). In the rare situations taken to represent the ejection of an element as a daugther cell, a partly freed element still rested at the bottom of a crater of the parent organism (Fig. 14).
Empty craters covered by a loose membrane, which might have contained one or more elements, were, however, extremely common.

A state of transition between the first and the second group of organisms was observed, as pieces of flat cisternae were often seen to be developing around a group of fine and coarsely flocculated chromatin as described for the first group. The cisternae also engulfed some of the ribosome-containing cytoplasm, resulting in the formation of elements characteristic for the second group (Figs. 6, 9, 10\& 11).

In a few cases a single pale Group 2 element was observed in an organism together with the elements characteristic of the transitory state between Group 1 and 2. In such cases the Group 2 element was positioned close to the limiting membrane of the organism, some distance away from the transitory-state elements (Fig. 10).

A third, less frequent group of organisms was characterized by having one or more pale nuclei or nucleus-like formations randomly scattered in the ribosome-containing zone of the cytoplasm. A few nondilated cisternae were normally positioned eccentrically around each nucleus-like body, but annulate lamellae were absent (Fig. 15). This gave the impression that the cytoplasm contained a number of small, 


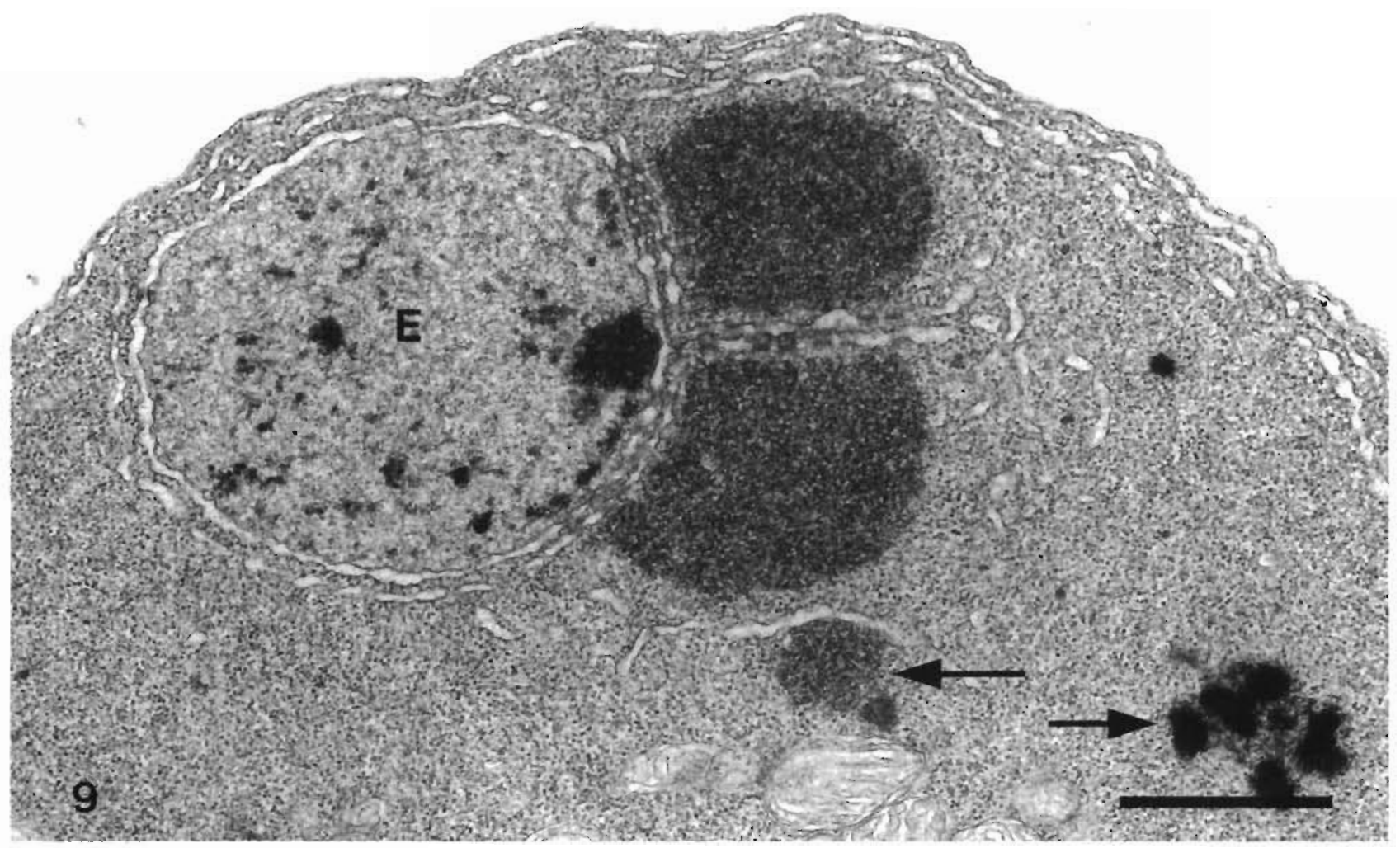

Fig. 9. Part of an extracellular organism, TEM. The organism contains a nucleus-like element (E). Two cisternae of annulate lamellae separate the nucleus-like element from 2 groups of chromatin, which are separated from each other by annulate lamellae. Membranes are being formed around these 2 groups of chromatin, whilst 2 other groups of chromatin are located separately in the cytoplasm (arrows). Note the 3 rows of cisternae along the periphery of part of the organism. Scale bar $=1 \mu \mathrm{m}$

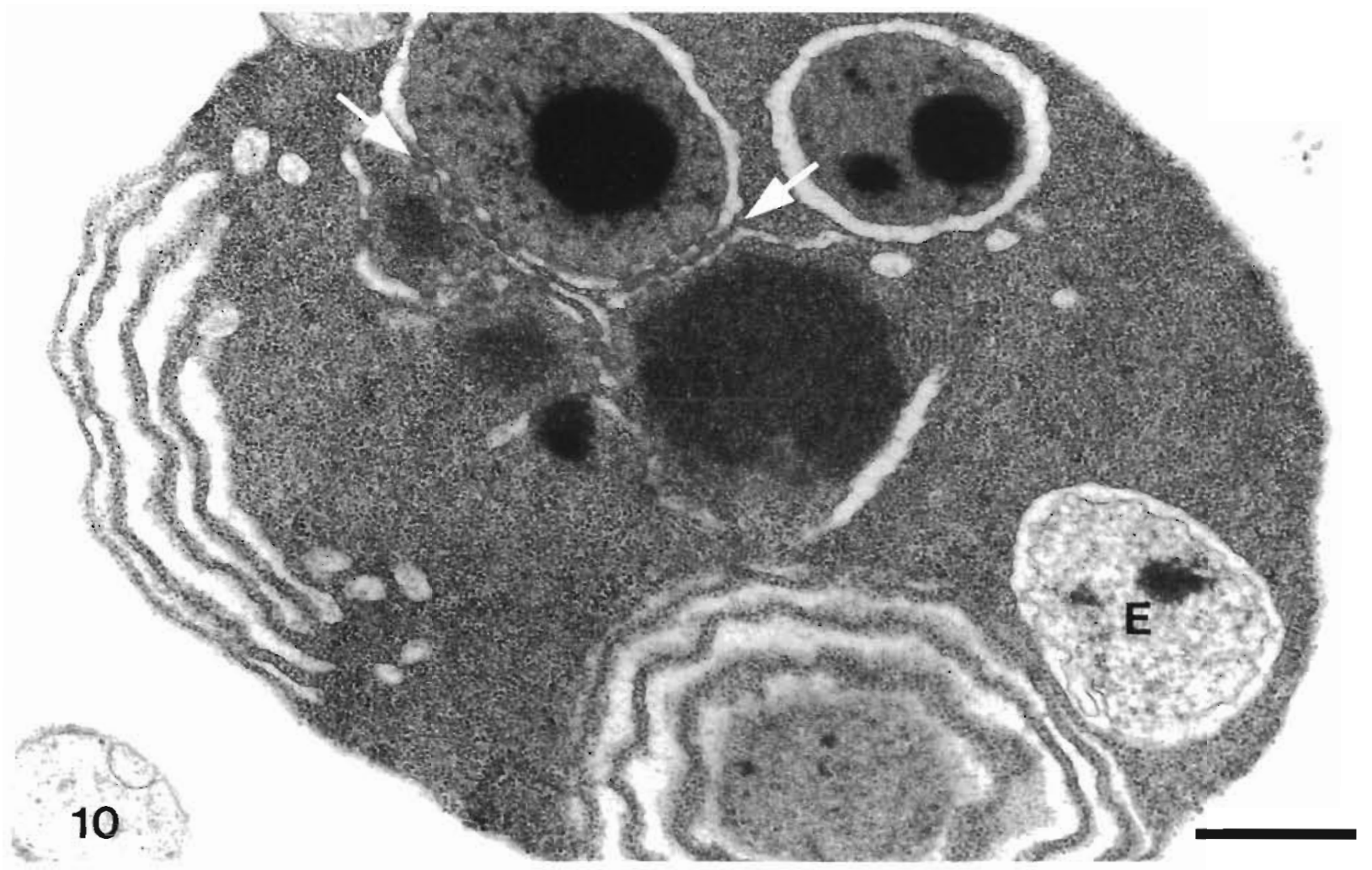

Fig. 10. Extracellular organism, TEM. The organism contains a degrading nucleus-like element (E) together with other elements which are being formed. Some of the adjoining elements are separated by 2 cisternae of annulate lamellae (arrows). Note 2 groups of differently orientated, stacked cisternae. Scale bar $=1 \mu \mathrm{m}$ 


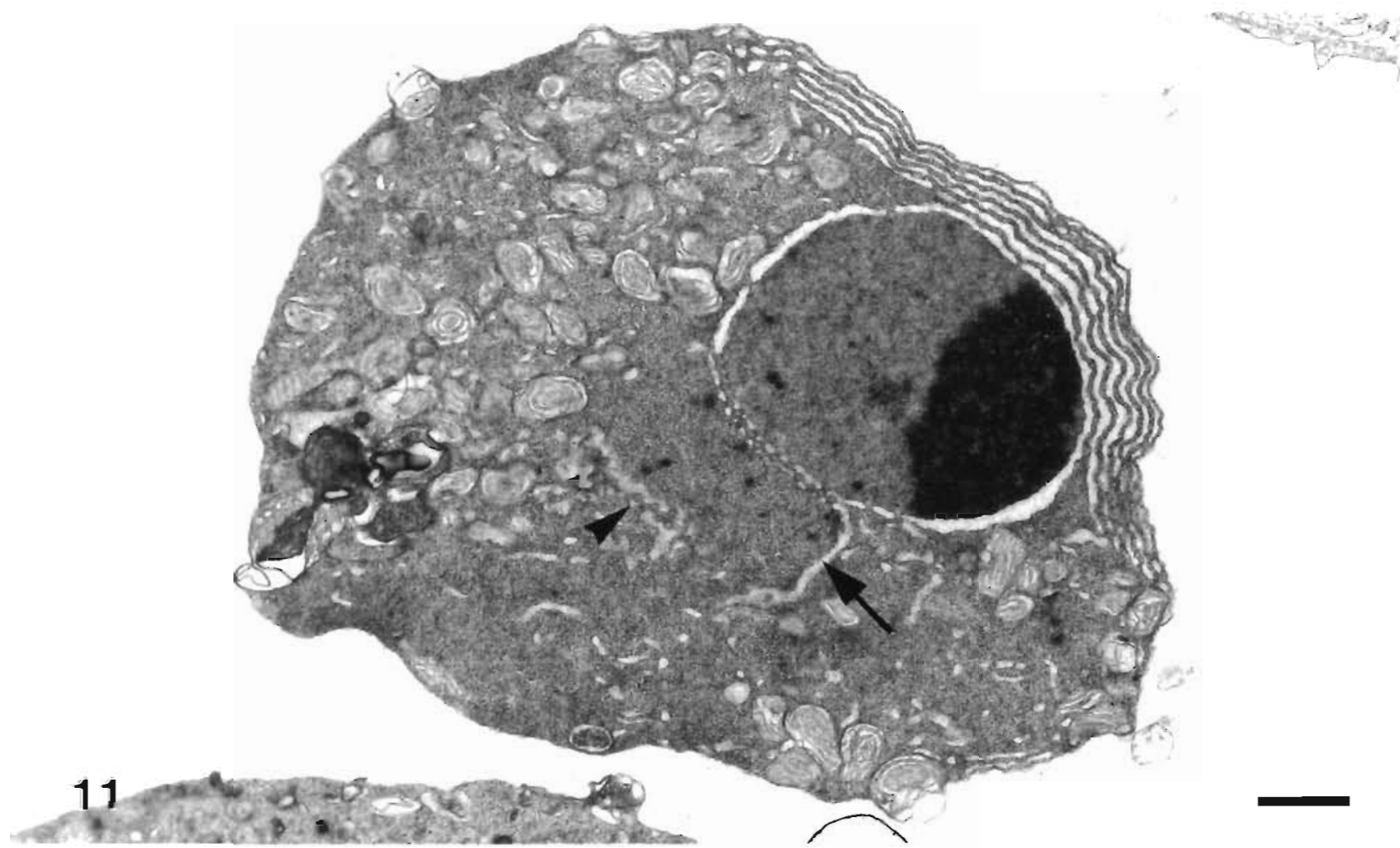

Fig. 11. Extracellular organism, TEM. The organism contains one element which is attached to another element that is only partly surrounded by a developing cisterna (arrow). A row of pores indicates that another element is positioned outside the section shown (arrowhead). Note also the group of 5 stacked cisternae along part of the organism's periphery. Such stacks of endoplasmic reticulum usually extend around about a quarter of the periphery of an organism. Scale bar $=1 \mu \mathrm{m}$

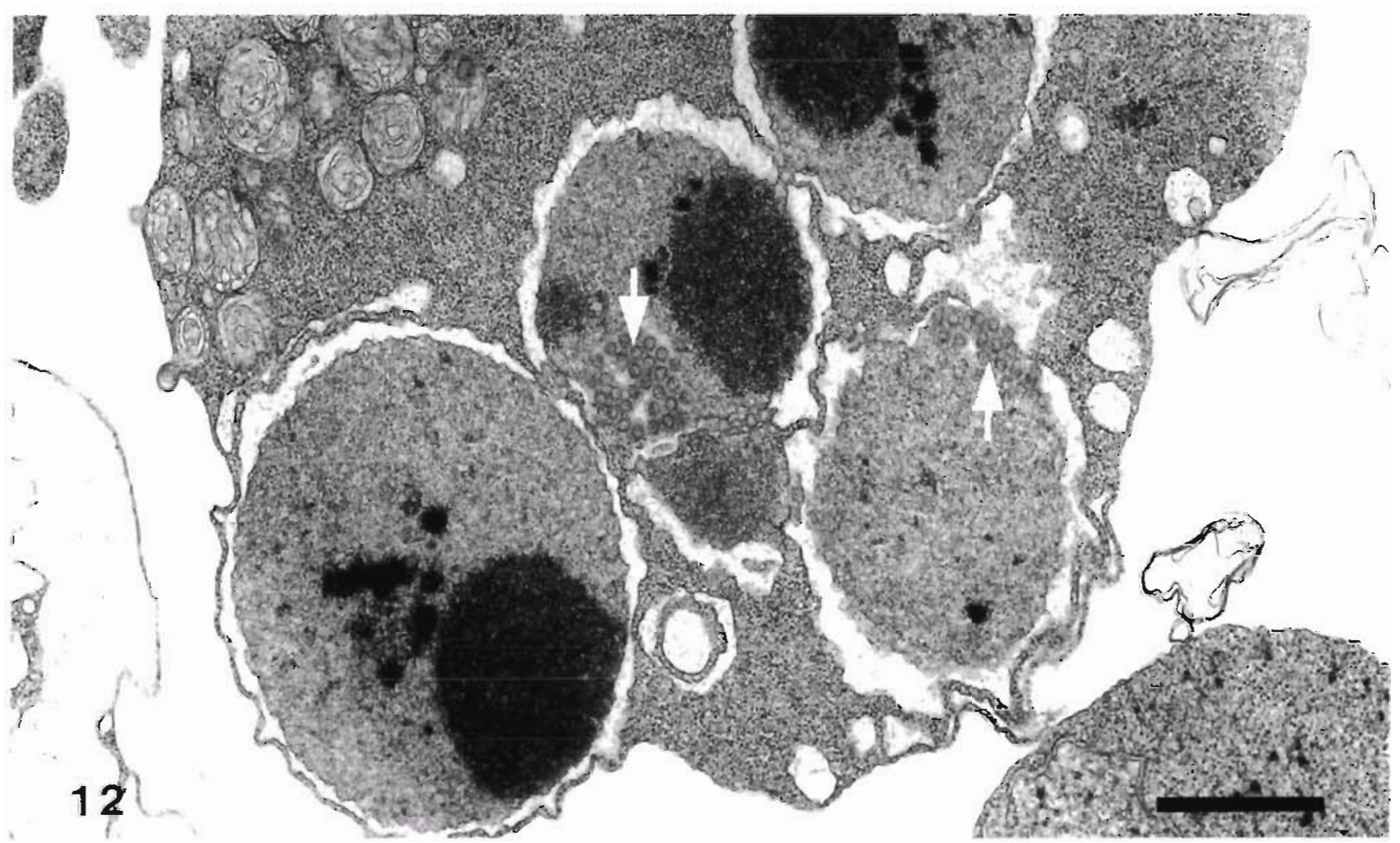

Fig. 12. Part of an extracellular organism, TEM. The organism contains 5 elements. Two groups of pores of tangentially cut annulate lamellae (arrows) indicate the presence of elements outside the plane of the picture. In 3 of the elements, the typical double configuration of coarsly and finely flocculated chromatin are seen. Scale bar $=1 \mu \mathrm{m}$ 


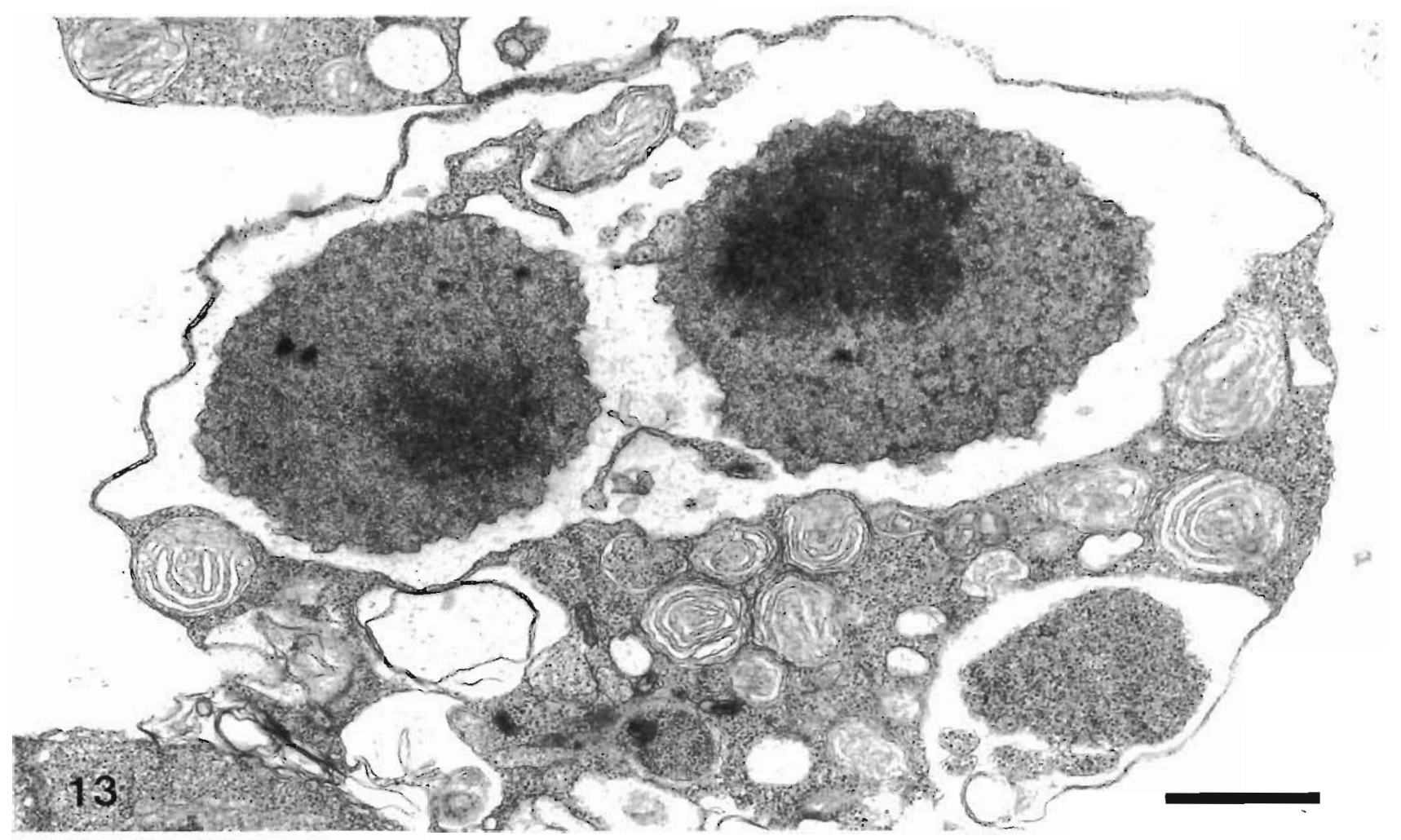

Fig. 13. Extracellular organism, TEM. The cisternae separatıng the 2 elements have apparently fused, rendering the elements free in one vacuole. Scale bar $=1 \mu \mathrm{m}$

nucleated daughter cells. An organism similar to such a small presumed daughter cell has been observed adhering to a larger organism (Fig. 16) To complicate an interpretation of our observations, an organism containing such possible daughter cells was in one case surrounded by a rim of less dense cytoplasm that could have belonged to an organism of an earlier generation (Fig. 15).

On many occasions a cell appeared to contain only a single large nucleus-like body but upon examination of all the sections of the cell it was often possible to find one or more transversing annulate membranes separating smaller fragments from the main part (Fig. 17).

The endoplasmic reticulum also showed at least 3 characteristic configurations. The most conspicuous was that of stacked, parallel flat cisternae separated

Fig. 14. Extracellular organism, TEM. An element possibly in the process of being released from the mother organism. Note that a peripheral cisterna has been formed in it (arrow), indicating that the element is in fact a daughter cell. Myelinlike structures are located beneath the daughter cell. Scale bar $=0.5 \mu \mathrm{m}$

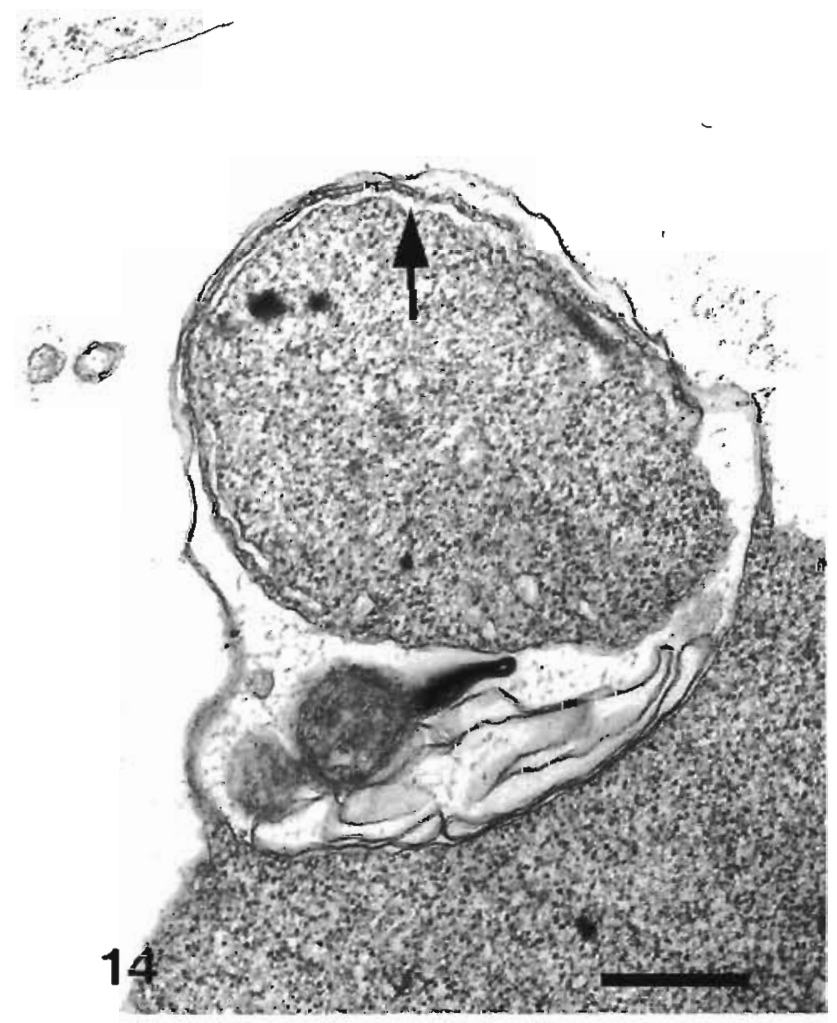




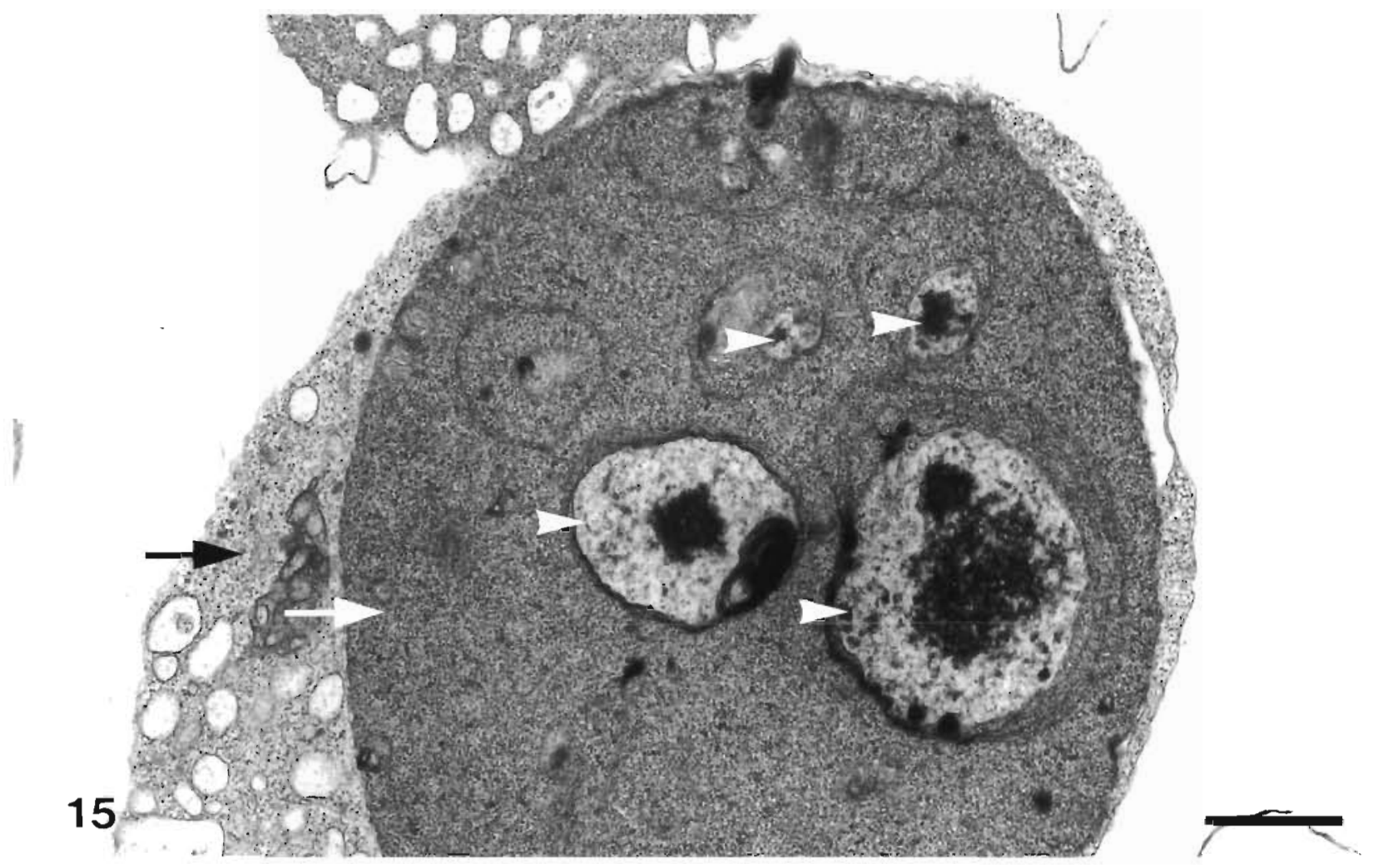

Fig. 15. Part of an extracellular organism. TEM. Nucleus-like bodies (arrowheads)-surrounded by one or more concentric cisternae - are scattered in a relatively electron-dense organism (white arrow) which lies inside a more lightly stained organism, possibly of a previous generation (black arrow). Note the absence of annulate lamellae. Scale bar $=1 \mu \mathrm{m}$

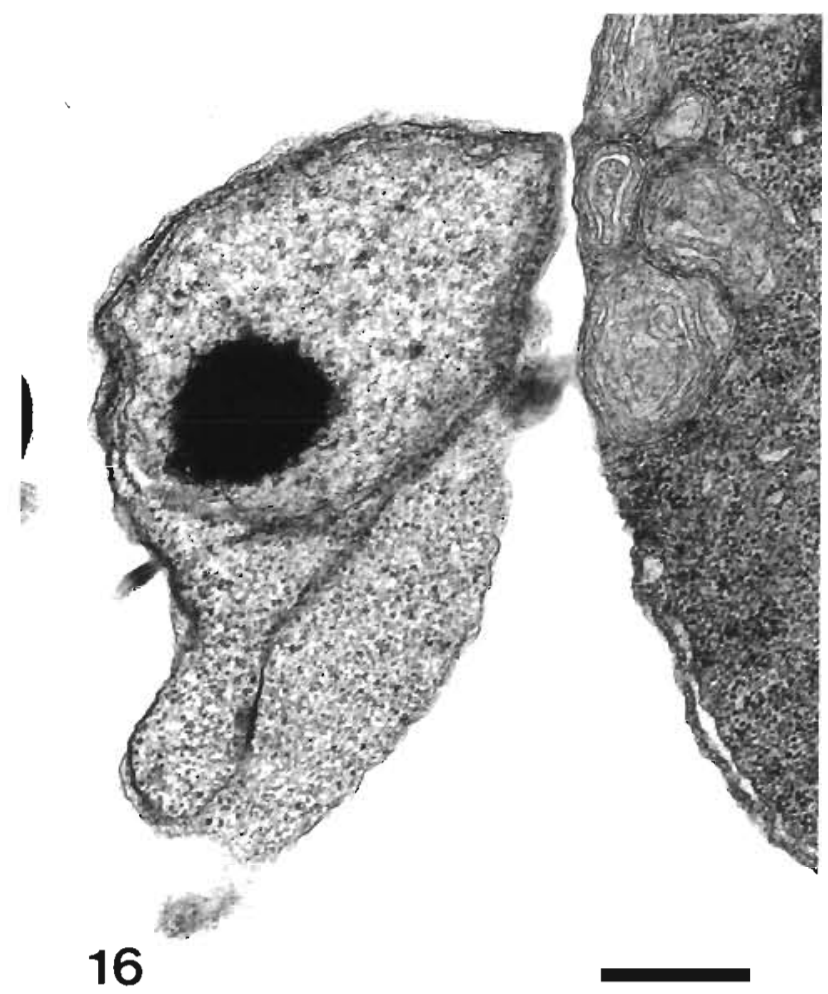

from the exterior and from each other by thin uniform layers of cytoplasm (Figs. 10 \& 11). Especially frequent in the smaller cells was a single flat cisterna situated beneath large areas of the cell surface (Fig. 18). Shorter strands of flat cisternae sometimes separated the ribosome-containing zone of the organism from the rest. Both kinds of cisternae could be intimately connected with a Golgi-like formation. The reticulum might also consist of strands of vacuoles, often in configurations as those of the cisternae, or it could be in the form of sporadically scattered small vacuoles. It should be noted, however, that both small and medium sized organisms sometimes apparently lacked a reticulum.

The mitochondria were gathered in a zone of the larger organisms (Fig. 6) while the smaller organisms apparently sometimes lacked mitochondria. The cristae were usually bowl- or jar-shaped, but could be tubular in developing mitochondria in small organ-

Fig. 16. Extracellular organisms, TEM. A small, apparently nucleated daughter cell adjacent to a larger organism. Scale bar $=0.5 \mu \mathrm{m}$ 


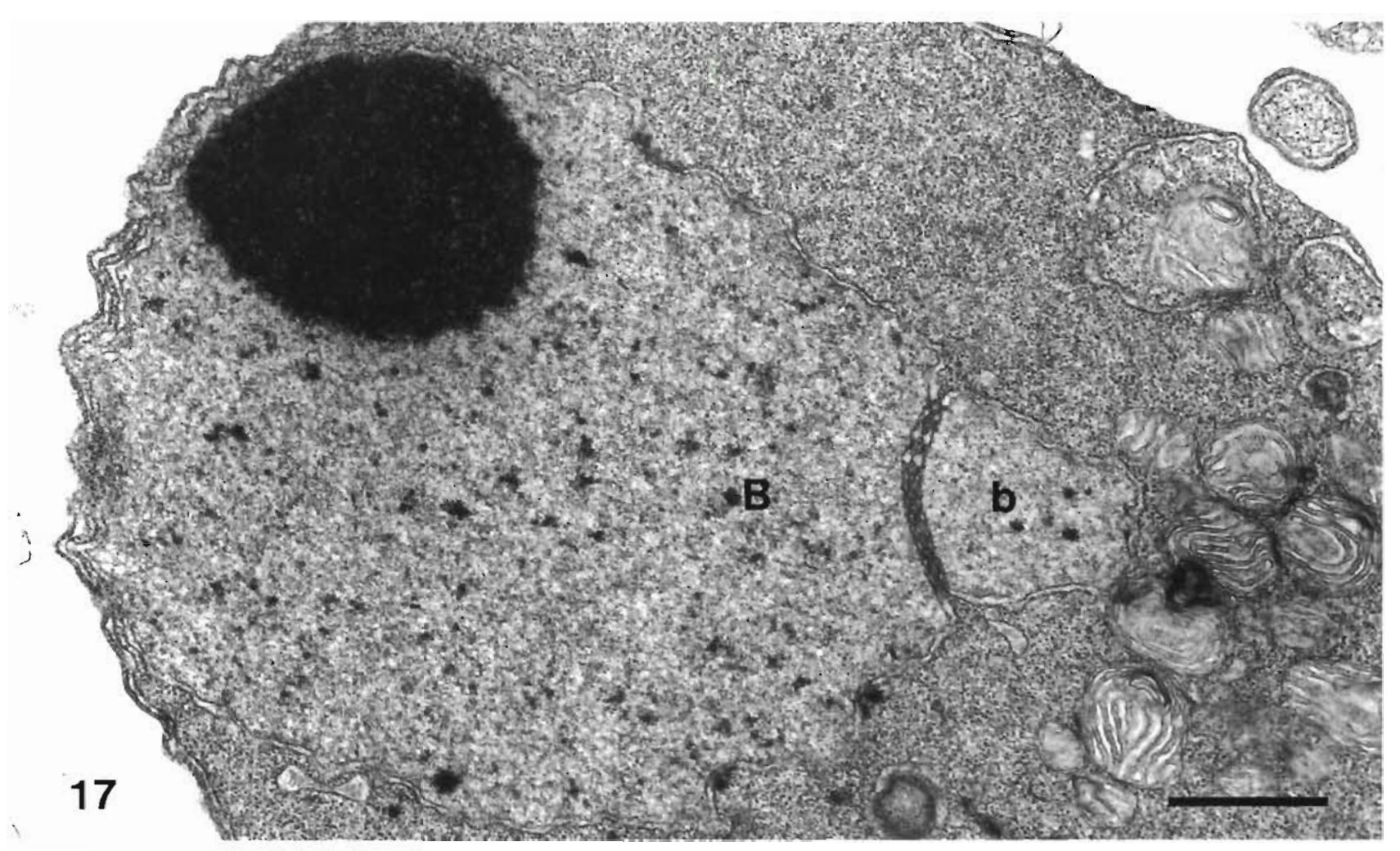

Fig. 17. Part of an extracellular organism contanıng a big nucleus-lıke body ( $B$ ) limited by a custerna, TEM Part of the nucleuslike body (b) is separated from the main part by annulate lamellae composed of 2 cisternae This organism is shown in Fig 2 . Scale bar $=1 \mu \mathrm{m}$

isms. The morphology of the mitochondria was sometimes disturbed by myelin figures that seemed to be in the process of being discharged (Fig. 4).

In addition to the forms of the organism described above, variants containing a common cisternal system - which partly surrounded many of the mitochondria - were infrequently observed (Fig. 19).

In the control embryos, no organisms were observed in the interstice between the yolk-membrane and the embryonic body and superficial tissues overlaying the yolk-membrane. In embryos with parastic spheres in the yolk, clusters of organisms were always seen at this location. A few degenerating intracellular forms of the organism were, however, observed in the controls together with an even lower number of viable-looking organisms.

Fig. 18. Extracellular organism adhering to a fish cell, TEM The contact zone between the organism and the fish cell is very tight. A dilated cisterna runs beneath a large part of the circumference of the organism, and a layer of vacuoles is positioned closely under the remaining surface. Scale bar $=1 \mu \mathrm{m}$

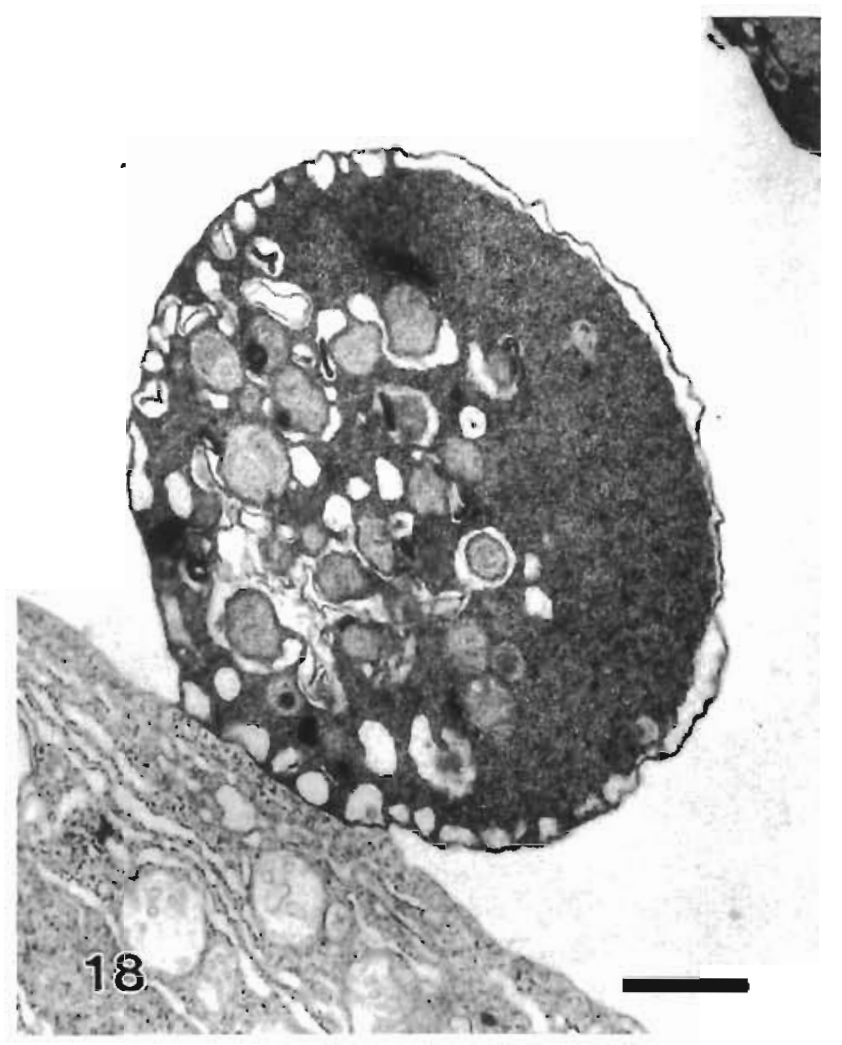




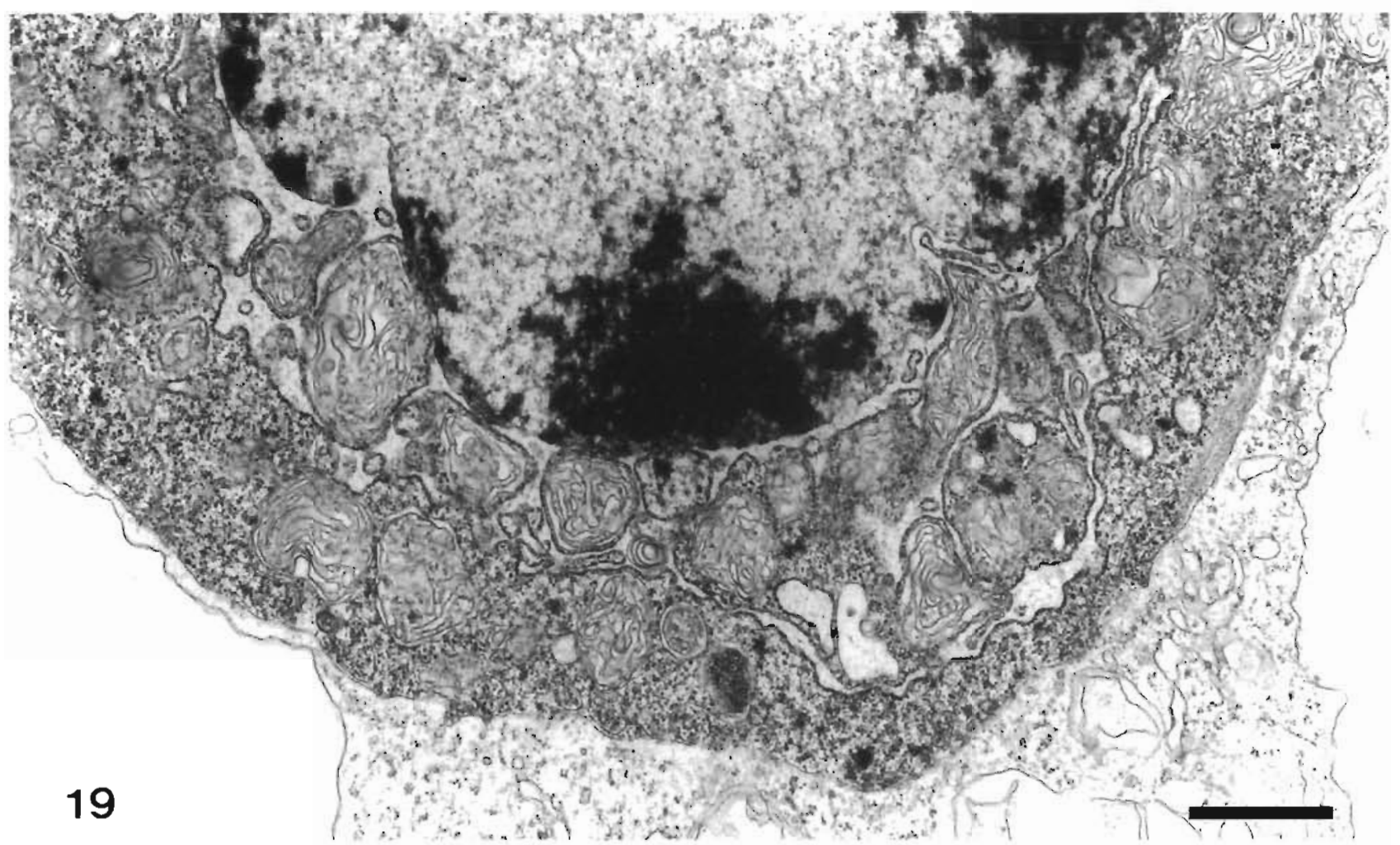

Flg. 19 Part of a nucleated, intracellular organism in the yolk-sac membrane, TEM The cell contains a common cisternal system which includes the permuclear cisterna. Many of the mitochondna, which are covered by a very thin layer of cytoplasm, are partly surrounded by this common cisternal system. Scale bar $=1 \mu \mathrm{m}$

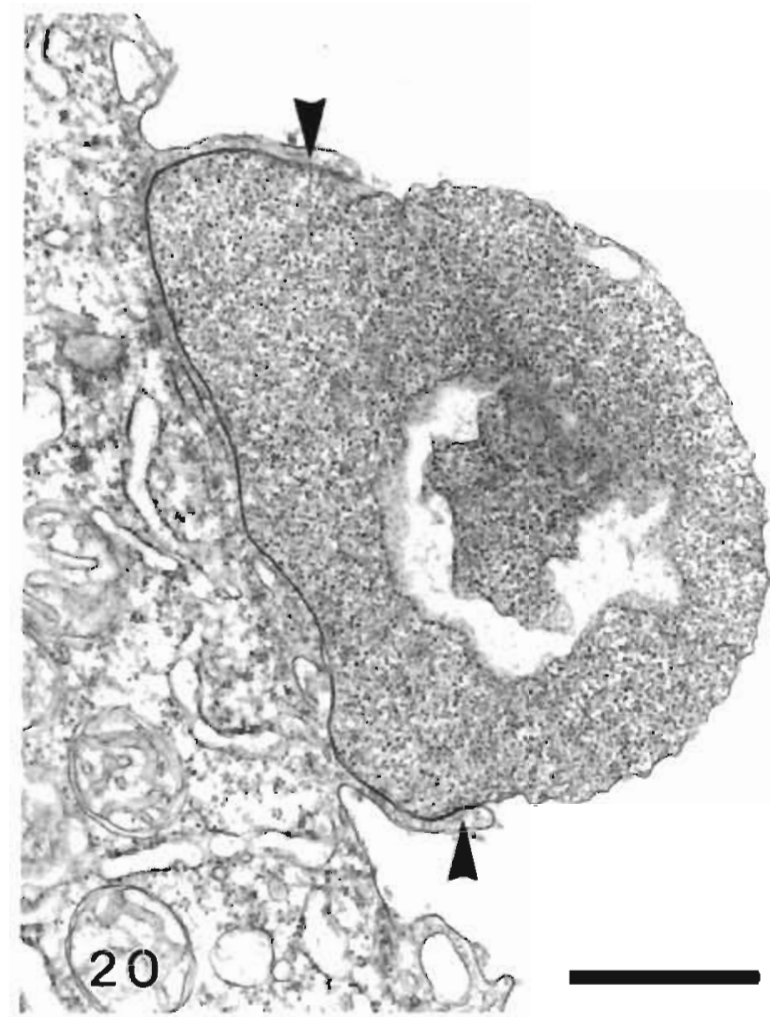

Contact between embryonic cells and the organism was accomplished either by molecular bridges at discrete points or more often by a very intimate adherence leaving no space left between the cell membranes (Fig 18). Although numerous sections of many embryos have been studied, the process of the organism invading embryonic cells has not been captured in tull. However, an embryonic cell had started to surround an organism (Fig. 20), possibly leading to endocytosis of it.

\section{Histochemistry}

The methyl green-pyronin staining of the chromatinlike matenal confirmed that the material was rich in DNA (Fig 21). The intensity and colour was exactly the same as the colour of the chromosomes in embryonic cells in mitosis.

Fig 20 Extracellular organism in the process of becoming surrounded by projections from the fish cell (arrowheads). The contact between the organism and the fish cell is very tight. Scale bar $=1 \mu \mathrm{m}$ 

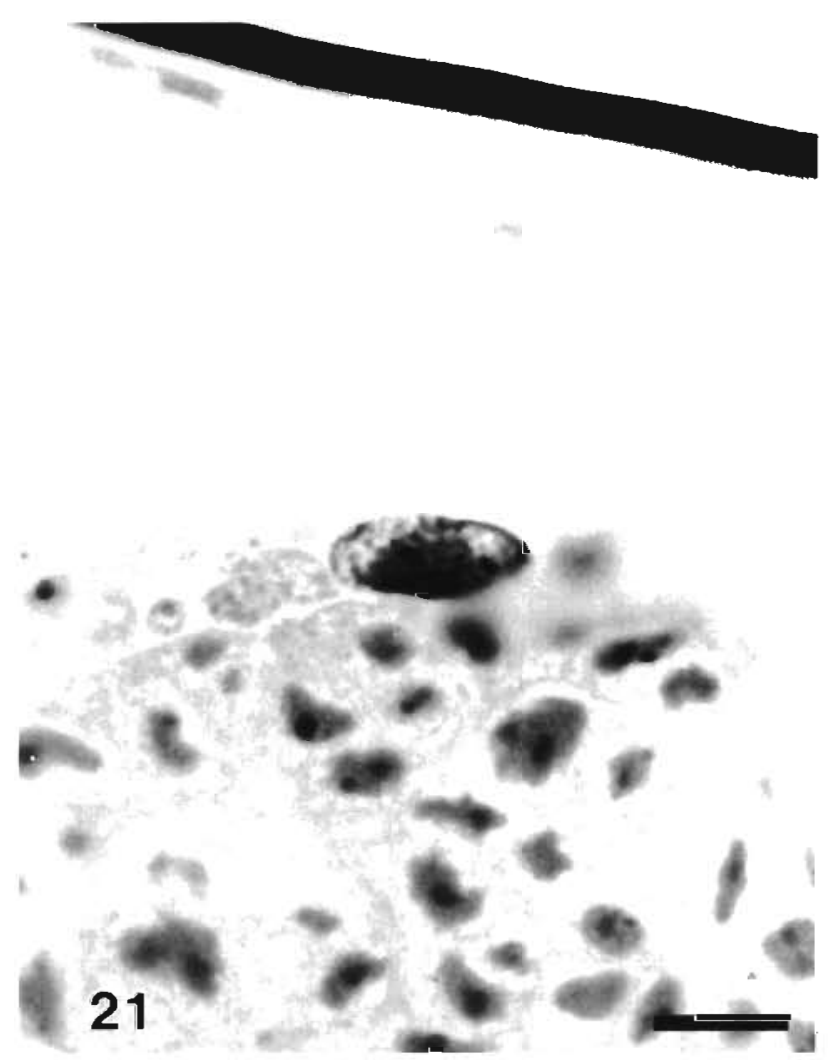

Fig. 21. Semi-thin section of a LR-White embedded embryo showing an intracellular organism with chromatin-like spheres. Scale bar $=10 \mu \mathrm{m}$

\section{DISCUSSION}

It has not been possible to find any description of a cell or an organism which resembles the present one, and we have therefore considered a number of hypotheses concerning its nature. Thus, it is possible that the organism might represent remains from the oocyte or perhaps be embryonic cells exhibiting an abnormal development. Alternatively, the organism could be degenerating, abortive forms of a parasite, or finally, it may be stages of an unknown parasite.

A seemingly strong point in favour of the first theory is the frequent occurrence of annulate lamellae (AL) in the organism, as this organelle has been reported in oocytes of many species. However, AL, which is a transient organelle that consists of stacked cisternae containing aligned pores (Merisko 1989) resembling the nucleopore complex (Cordes et al. 1995), are now known to be potential cellular constituents in all types of animal tissue (Kessel 1989, Merisko 1989) and have even been described in plants. AL can be induced in somatic cells by variations in temperature, by starvation, viral infections, oncogenic transformations or treatment with hormones or a variety of chemicals (Kessel 1983, 1989, 1992). Thus, the structure is not specific for germ-cells. Further, AL in immature oocytes usually occur in extensive quantities (Kessel 1983), and in studies that have been made of $\mathrm{AL}$ in maturing oocytes of fish, amphibia and mammals, the AL have completely disappeared during meiotic maturation (Aizenshtadt \& Detlaf 1972, Zamboni 1972, Kessel \& Subtelny 1981). Also, we have never seen AL in embryonic cod cells, and AL have not been described in newly hatched larvae of this species (Morrison 1993).

There are 2 major obstacles to the second theory, i.e. that the organism might represent abnormal embryonic cells. Only macrophages and similar cells have the ability to take up defective cells, and embryonic cells containing small organisms did not have the appearance of such cells but were in all other respects similar to the neighbouring cells. The intracellular organisms seem to be derived from the small extracellular ones, as both forms have an identical morphology. Further, the morphology and the multiplication of the organism show no resemblance at all to those of the embryonic cells, and in contrast to embryonic cells, neither chromosomes nor mitoses have been observed in any of the organisms. In brief, the organism has an alien appearance and behaviour relative to those of the embryonic cells.

The third possibility we have considered is that the organism might be abortive stages of a protistan parasite undergoing degradation. The zone containing large vacuoles and empty craters in the extracellular stages that produced daughter elements (Figs. 10, 11, $12 \& 13$ ) had degrading cellular components inside the vacuoles. Such degrading cellular constituents, e.g. mitochondria and loose membranes, were also observed extracellularly, but in contrast to the elements/daughter cells, such cell fragments were not internalised by the embryonic cells. The remaining zones, as well as the elements in these organisms, however, did not show any signs of degradation such as dilation, lysis, burst of membranes, etc.; neither were there any signs of apoptosis.

In cases where intracellular organisms were degraded, they were most often destroyed to the extent that they were reduced to black, granulated material with hardly any discernible structures (not shown), identified as likely organisms exclusively by their size and the possible presence of remains of a nucleus-like body. In no other cases did inter- and intracellular daughter elements/daughter cells appear to be degenerating. It should be noted that viable-looking intracellular organisms were usually not surrounded by a fish cell membrane so they were apparently not undergoing digestion inside a vacuole. In contrast, the organism may elicit a reaction which results in forma- 
tion of small vacuoles or in an electron-lucent appearance of neighbouring areas of embryonic cytoplasm, indicative of destruction caused by the internalised organism.

The hypothesis that the organisms are parasitic cells multiplying in an hitherto unseen way remains. Unfortunately, a developmental link between the yolk parasite and the present organism has not been observed. However, spheres in the yolk void of nuclei and with degenerating organelles were often encountered. Such spheres may have released their nuclei in the form of small inter-and intracellular organisms after which the spheres degraded. If this were the case, the degradation had already been completed in the control embryos in which no spheres were seen.

In contrast to the very low prevalence of the yolk parasite in cod embryos from the Norwegian Sea (B. H. Pedersen unpubl.), prevalences are high in the Baltic Sea, but the Baltic mother fish of the control embryos had an extremely low rate of infection with the yolk parasite. The control embryos did not contain a visible yolk parasite, and the main site of predelection of the present organism, i.e. the subdermal space, contained no organisms, but a very low number of mostly decaying intracellular stages were found by TEM. As no biochemical/genetic marker exists for the organism, the final diagnosis rests with TEM. This precludes a confident diagnosis of organism-free wild spawners (by the time a TEM diagnosis can be made, the short spawning season is over).

The polymorphism of the organism makes a concise description difficult. The lack of known comparable structures and the fact that only embryos and therefore probably also organisms of a certain age and degree of development were examined make our description incomplete. Thus, it has not been possible to establish with certainty whether the structures referred to as elements (Figs. 10,12 \& 13) represent daughter cells or nuclei. The fact that several such elements can be contained in one vacuole and the occasional presence of mitochondria and cisternae in elements indicate that they are daughter cells. The fact that similar organisms can be observed both intra- and extracellularly and the presence of empty craters in many of the larger organisms support this idea. In contrast, the structures described as nucleus-like bodies are not found in vacuoles but are scattered throughout the cytoplasm without being connected to each other with special links such as annulate lamellae. The presence, however, of a single apparently degenerating nucleus-like body in a few organisms containing developing elements (Fig. 10) and the presence of one or more nuclei in other organisms (Fig. 15) indicate that the stages that the organism goes through in the embryo are highly complicated.
The organism has some very peculiar features, i.e. the frequent occurrence of AL and unusual chromatin configurations. AL have been known for more than 40 yr but their origin, fate and functions are unknown. Most authors believe that $\mathrm{AL}$ are associated with a high level of cellular metabolism or have a role in cell growth and differentiation (e.g. Wang et al. 1992, Masuda et al. 1994, Watanabe et al. 1995). The hypotheses as to the significance of AL have so far not been substantiated, so we cannot assess the functional implications of this organelle in the present organism.

The chromatin configurations of the organism seem to include nuclei of a conventional appearance surrounded by a nucleolemma in addition to chromatin condensations which lack limiting membranes and which can be separated from similar condensations by 2 AL cisternae. Further, cisternae appear in the process of surrounding chromatin together with part of the ribosome-containing cytoplasm. To our knowledge this kind of polymorphism and multiplication has not been previously described, and we are unable to interpret its significance.

Unfortunately, the embedding media did not allow RNA-ase penetration, although this ought to have been possible, and this precludes a more precise description of what, on TEM, has the distinct appearance of chromatin. However, using light microscopy, methyl green-pyronin staining of semi-thin sections revealed groups of DNA containing chromatin-like lumps in the organisms. Biological material from future spawning seasons will be used to compare neighbouring sections by TEM and light microscopy for further description of the chromatin configurations.

Classification of the organism is still an open question, but it seems to be a protist. Its morphological characteristics are, however, not compatible with those of the protozoa presently known to parasitize fish (cf. Lom \& Dyková 1992). Future studies may establish the systematic position of the organism by investigating part of its DNA sequence and by following its further development in the host.

Acknowledgement. This study was supported by a grant from the Carlsberg Foundation (B.H.P.)

\section{LITERATURE CITED}

Aizenshtadt TB, Detlaf TA (1972) Ultrastructure of Stellate Sturgeon oocytes during maturation. Report 1. Annulate lamellae and Golgi complex. Sov J Dev Biol 3:220-229

Cordes VC, Reidenbach S, Franke WW (1995) High content of a nuclear pore complex protein in cytoplasmic annulate lamellae of Xenopus oocytes. Eur J Cell Biol 68:240-255

Kessel RG (1983) The structure and function of annulate lamellae: porous cytoplasmic and intranuclear membranes. Int Rev Cytol 82:181-303 
Kessel RG (1989) The annulate lamellae-from obscurity to spotlight. Electron Microsc Rev 2:257-348

Kessel RG (1992) Annulate lamellae: a last frontier in cellular organelles. Int Rev Cytol 133:43-120

Kessel RG, Subtelny S (1981) Alteration of annulate lamellae in the in vitro progesterone-treated, full-grown Rana pipiens oocyte. J Exp Zool 217:119-135

Lom J, Dyková I (1992) Protozoan parasites of fishes. Dev Aquacult Fish Sci 26:1-315

Masuda M. Yamazaki K, Kanzaki J, Hosoda Y (1994) Ultrastructure of melanocytes in the dark cell area of human vestibular organs: functional implications of gap junctions, isolated cilia, and annulate lamellae. Anat Rec 240 : 481-491

Merisko EM (1989) Annulate lamellae: an organelle in search of a function. Tissue \& Cell 21:343-354

Morrison CM (1993) Histology of the Atlantic cod, Gadus morhua: an atlas, Part 4. Eleutheroembryo and larva. Can Spec Publ Fish Aquat Sci 119:1-496

Pedersen BH (1993) Embryos and yolk-sac larvae of turbot Scophthalmus maximus are infested with an endoparasite

Responsible Subject Editor: Wolfgang Körting, Hannover, Germany from the gastrula stage onwards. Dis Aquat Org 17:57-59

Pedersen BH, Buchmann K, Køie M (1993) Baltic larval cod Gadus morhua are infested with a protistan endoparasite in the yolk sac. Dis Aquat Org 16:29-33

Pedersen BH, Koie M (1994) A protistan endoparasite in embryos and yolk-sac larvae of cod Gadus morhua and turbot Scophthalmus maximus. Dis Aquat Org 19:39-46

Perry S, Reynolds J (1956) Methyl-green-pyronin as a differential nucleic acid stain for peripheral blood smears. Blood 11:1132-1139

Wang NS, Liu C, Emond J, Tsao MS (1992) Annulate lamellae in a large cell lung carcinoma cell line with high expression of tyrosine kinase receptor and proto-oncogenes. Ultrastruct Pathol 16:439-449

Watanabe S, Ito T, Shirai M, Arima K, Nishioka M (1995) Electron microscopic studies of peripheral blood mononuclear cells in chronic type $C$ hepatitis treated with interferon-alpha. Ultrastruct Pathol 19:1-8

Zamboni L (1972) Comparative studies on the ultrastructure of mammalian oocytes. In: Biggers $J$, Schuetz A (eds) Oogenesis. University Park Press, Baltimore, p 5-46

Manuscript received: October 21, 1996

Revised version accepted: April 20, 1997 